\title{
Synthesis, characterization and thermokinetic analysis of the novel sugar based styrene co-polymer
}

\author{
Fatma Cetin Telli ${ }^{* *}$ (1) \\ ${ }^{1}$ Department of Chemistry, Faculty of Science, Ege University, Bornova, İzmir, Turkey \\ *fatma.cetin@ege.edu.tr
}

\begin{abstract}
A new $\alpha$-chloralose (1,2-O-(R)-trichloroethylidene- $\alpha$-D-glucofuranose)-based copolymer of styrene (PSVTEG) (2) was synthesized from vinyl (hydroxyl) furan monomer (1) and styrene by a conventional free radical polymerization reaction. The thermal decomposition kinetics of polymer were investigated by means of thermogravimetric analysis in dynamic nitrogen atmosphere at different heating rates. The apparent activation energy for the main stage thermal decomposition of the copolymer PSVTEG (2) was calculated using the Flynn-Wall-Ozawa and found to be $159.0 \pm 3 \mathrm{kj} / \mathrm{mol}$. In addition, the activation energy value was calculated according to Coats-Redfern method and found to be compatible with the obtained result. The thermogram of the glycopolymer (PSVTEG) (2) has two decomposition stages and the calculated activation energy indicated that the main degradation stage is a nonspontaneous process (integral form $1 /(1-\alpha)^{2}$ for $\mathrm{F}_{3}$ ).
\end{abstract}

Keywords: glycopolymers, carbohydrate based vinyl copolymer, $\alpha$-chloralose, thermal analysis, decomposition kinetic.

How to cite: Telli, F. C. (2020). Synthesis, characterization and thermokinetic analysis of the novel sugar based styrene co-polymer. Polímeros: Ciência e Tecnologia, 30(2), e2020019. https://doi.org/10.1590/0104-1428.02620

\section{Introduction}

Glycopolymer is synthetic polymer with pendant carbohydrates ${ }^{[1]}$. Carbohydrates are important natural sources of building blocks for the synthesis of biodegradable polymers. They are also easily accessible and some are even coming from agricultural wastes ${ }^{[2]}$. Furthermore, they are found in different kinds of chemical structures with great stereochemical diversity and constituted as renewable sources as being more sustainable than fossil fuels ${ }^{[3,4]}$. Recently, the basic raw materials used for polymers have expanded by sugars including glucose, galactose, fructose and sucrose. Therefore, carbohydrates are excellent substitutes for products of fossil origin for industrial developments ${ }^{[5]}$. Chemically containing sugar moieties onto synthetic polymers are induvidual methods for the functionalization of synthetic polymers. With these use of these methods, the polymer is not only functionalized, but also other desirable properties such as biodegradability, biocompatibility and biorenewability can be achieved ${ }^{[6]}$. Thus, these could be avaiable alternatives for developing environmental friendly products. Synthetic carbohydrate polymers were investigated as biodegradable, biocompatible, biorenewable materials as water absorbents, chromatographic supports, drug delivery systems and medical devices $^{[7,8]}$, in dental medicine, bioimplants, contect lenses, tissue engineering and electrochemical application $\mathbf{s}^{[9-12]}$. Moreover, polymers with pendant carbohydrate moieties have been useful in clinical diagnostic trials and targeted gene therapies. The use of these polymers are essential in surgery, prosthetic systems and pharmacology ${ }^{[, 13-16]}$. In addition, using sugar functionalized petrochemical polymers of polystyrene for use as biodegradable polymers is a newly discovered application of a sugar linked synthetic polymer ${ }^{[17,18]}$.
During the last three decades, the synthesis of glycopolymers became popular with an effort towards biomimics and most of the attempts were based on the polymerization of monomers containing carbohydrate moieties ${ }^{[15-25]}$. These glycomonomers (sugar carrying monomers) were reported to be polymerized by controlled/living radical polymerisation, radical, anionic, cationic ring-opening polymerization, ring-opening metathesis polymerization and post-functionalization techniques ${ }^{[1,24,25]}$. Until the last decade, there had been limited attempts to react a functional polymeric backbone with a carbohydrate to obtain a glycopolymer. A significant reason for this was the difficulty of introducing sufficiently reactive pendant groups onto the polymer backbone to react with carbohydrates. With respect to a sustainable chemistry, unsaturated sugar monomers are useful building blocks for copolymers with special properties like biocompatibility, biodegradability, hydrophilicity/hydrophobicity balance and skin compatibility. These properties are of major importance in many fields such as pharmaceuticals, drugs and cosmetics. Up to now; several saccharide monomers have been investigated in free radical polymerization with a wide range of commercially available co-monomers. Vinylsaccharides give rise to polymers bearing sugar appendages in the side chains ${ }^{[26]}$. For example, sugar-containing vinyl monomers were synthesized from isopropylidene ${ }^{[27]}$, chloralosed ${ }^{[28]}$ and other protected sugars ${ }^{[6,29]}$. Additionally, poly(vinyl saccharide)s attracted much attention since vinyl sugars can easily be copolymerized with various comonomers. Thus, the resulting copolymers have a chemically stable $\mathrm{C}-\mathrm{C}$ backbone and hydrophilic side chains. Klein and coworkers have studied the synthesis and solubility of poly(vinyl saccharide) ${ }^{[30,31]}$. 
Nakamae et. al have copolymerized 2-(glycosyloxy)ethyl methacrylate with methyl methacrylate or styrene and investigated the surface properties of cast films ${ }^{[32,33]}$. Wulff and coworkers have investigated the synthesis of $C$-glycosyl compounds containing polymerizable double bonds without protecting groups. They have used poly(vinyl saccharide)s with $N, N$-dimethylbarbituric acid as linkers between sugar and styrene ${ }^{[34,35]}$. Other types of vinyl sugar monomers and polymers have been reviewed elsewhere ${ }^{[36,37]}$. Since poly(vinyl sugar)s constitute polymers of a new structural type, they may have high potentials in modifying the surface of conventional polymer materials and improve the antistatic property, dyeability, adhesion, printability, and biocompatibility of bulk polymers ${ }^{[38]}$.

Monosaccharides mostly react in their furanose forms with chloral to give trichloroethylidene acetals. Chloraloses ( $\beta$-chloralose or $\alpha$-chloralose) have been prepared by the simple reaction of chloral and glucose ${ }^{[39]} \cdot 1,2-O-(\mathrm{R})-$ trichloroethylidene-D-glucofuranose is a commercially available compound, also known as $\alpha$-chloralose, which is used as an anesthetic for animals ${ }^{[40,41]}$. Unlike most acetals, $1,2-O$-trichloroethylidene acetals are very stable as protecting groups under acidic conditions due to the inductive effect of the trichloromethyl group. In addition, this protecting group is stable under mildly basic conditions. However, they are converted to the more reactive ketene acetals in the presence of strong bases such as potassium tert-butoxide. The only reported method for the removal of this protecting group is a Raney Nickel procedure ${ }^{[42]}$. Additionally, trichloroethylidene acetals are suitable protecting groups for the synthesis of some biologically important compounds such as amines ${ }^{[43]}$, orthoesters ${ }^{[44]}$, spiroendoperoxides ${ }^{[45]}$, spirodifuranoseç ${ }^{[4]]}$, oxetanes ${ }^{[47]}$, NHC ligands ${ }^{[48]}$, Schiff base $^{[49]}$, glyconanoconjugates ${ }^{[50]}$, etc.

In this work, new vinyl (hydroxyl) furan monomer (1) of $\alpha$-chloralose has been synthesized (Scheme 1) and characterized by Fourier transform infrared spectroscopy (FTIR), elemental analysis and optical rotation. In addition, it is used for the preparation of copolymer styrene (2) (Scheme 2). The thermal degradation kinetics of the copolymer was studied to compare its thermal properties. The apparent activation energies for thermal degradation of the copolymer were obtained by using Flynn-Wall-Ozawa and Coats-Redfern methods. Accordingly, in the further studies, the new carbohydrate-based copolymer of styrene will be a good candidate to prepare the metacomposites with negative electromagnetic parameters by a biomass conversion method ${ }^{[51-53]}$.

\subsection{Kinetic Analysis ${ }^{[54-56]}$}

Thermogravimetric analysis can be used for the determination of the degradation kinetics of many polymers. In general, the thermal degradation reaction of a solid polymer is shown as:

$$
A_{\text {solid }} \rightarrow B_{\text {solid }}+C_{\text {gas }}
$$
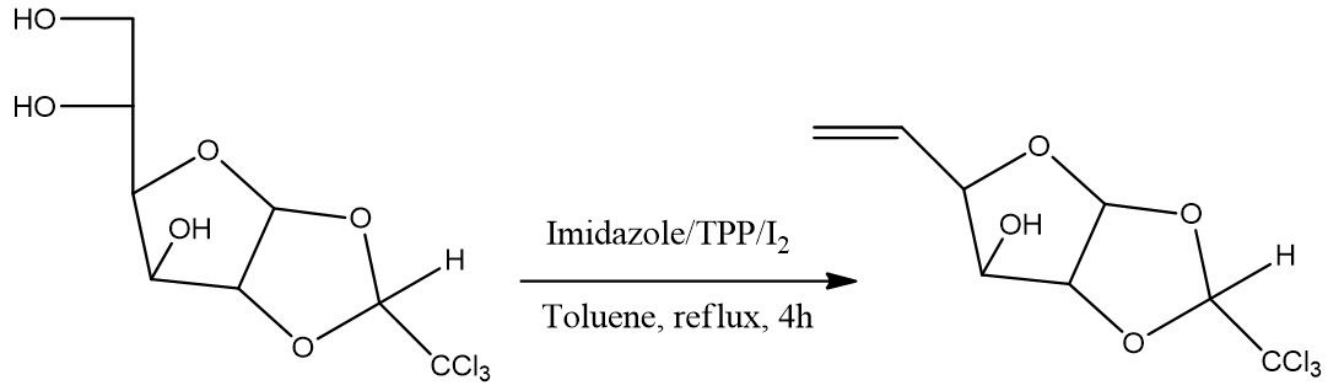

1

Scheme 1. Synthesis of new vinyl (hydroxyl) furan monomer (1) from $\alpha$-chloralose.
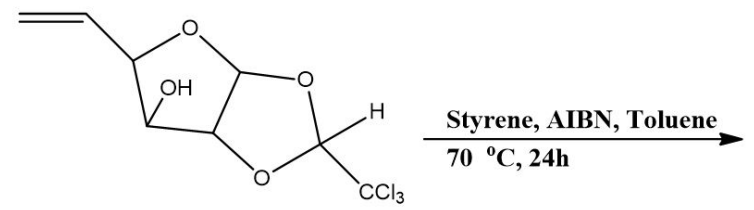

1

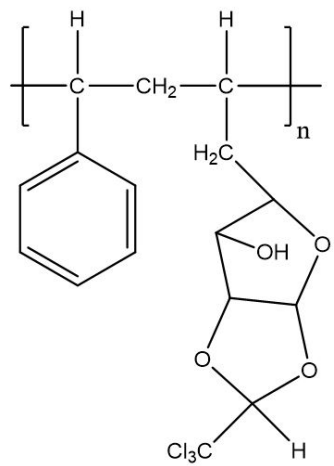

2

Scheme 2. Synthesis of the new copolymer styrene (2) from vinyl (hydroxyl) furan monomer (1). 
where $\mathrm{A}$ is the starting material, $\mathrm{B}_{\text {solid }}$ and $\mathrm{C}_{\mathrm{gas}}$ are the solid residue and the gas product, respectively. The following typical kinetic equation is generally expressed by the thermal degradation kinetics of the polymers.

$$
r=d \alpha / d t=k .(T) \times f(\alpha)
$$

where $\mathrm{T}$ is the absolute temperature $(\mathrm{K})$; $r$ is the conversion per $\mathrm{f}(\alpha)$ unit time $(t)$ is the conversion function which represents the reaction model. The degree of conversion $(\alpha)$ is calculated by Equation 2 where $\mathrm{m}_{\mathrm{o}}, \mathrm{m}_{\mathrm{t}}$ and $\mathrm{m}_{\mathrm{f}}$ are the weights of sample before degradation, after complete degradation and at time $t$, respectively.

$$
\alpha=m_{o}-m_{t} / m_{o}-m_{f}
$$

The Arrhenius equation is the reaction constant which can be expressed by calculating $\mathrm{k}$

$$
k(T)=A_{o} e^{-(E / R T)}
$$

where $\mathrm{A}$ is called pre-exponential factor, $\mathrm{R}$ is the gas constant and $\mathrm{E}$ is the activation energy

By combining Equation 1 and Equation 3 the following equation is obtained

$$
d \alpha / d t=A_{o} e^{-(E / R T)} x f(\alpha)
$$

According to the kinetic theory for the non-isothermal decomposition reactions, the fractional conversion $\alpha$ is expressed as a function of temperature which depends on the time of heating. Therefore, the heating rate $(\beta)$ can be described as:

$$
\beta=d T / d t
$$

that Equation 6 is modified as follows:

$$
d \alpha / d T=(1 / \beta) A_{o} e^{-(E / R T)} x f(\alpha)
$$

Equation 5 and Equation 6 are the basis for the many equations derived to evaluate thermal analysis data.

\subsubsection{Coats-Redfern Method ${ }^{[57]}$}

This method is based on the following equation

$$
\ln \left(g(\alpha) / T^{2}\right)=\ln (A R / E \beta(1-2 R T / E))-(E / R T)
$$

as $E$ is calculated from the slope $-E / R$ of the plot $\ln \left(g(\alpha) / T^{2}\right)$ versus $1000 / T$ which is a straight line. The most commonly used reaction models can be estimated for the solid-state processes by calculating the possible thermal degradation mechanism. The activation energy calculated by using this method was found to be as $159.2 \pm 3 \mathrm{kj} / \mathrm{mol}$.

\subsubsection{Flynn-Wall-Ozawa (FWO) Method ${ }^{[58,59]}$}

In this method, there is no need of any knowledge for the reaction mechanism for the calculation of the activation energy. The activation energy (E) and pre-exponential factor (A) are not dependent on the fraction of degradation while they depend on temperature. This method uses Equation 8.

$$
\log (\alpha)=\log (A E / R)-\log \beta+\log p(E / R T)
$$

Equation 9 is obtained by means of the Doyle approximation.

$$
\log \beta=\log (A E / R)-\log (\alpha)-2.315-0.4567(E / R T)
$$

Thus, from the slope $-\mathrm{E} / \mathrm{R}$ of the linear plot of $\log$ $\beta$ versus $1000 / \mathrm{T}, \mathrm{E}$ is readily obtained. The activation energies calculated by using this method was found to be $159.0 \pm 3 \mathrm{kj} / \mathrm{mol}$.

\section{Experimental}

\subsection{Materials}

1,2-O-(R)-trichloroethylidene- $\alpha$-D-glucofuranose ( $\alpha$ - chloralose) (stated purity $\geq 98 \%$ ), triphenylphosphine (TPP) (stated purity $\geq 99 \%$ ), imidazole (stated purity, $99 \%$ ), iodine $\left(\mathrm{I}_{2}\right)$ (stated purity $99 \%$ ), toluene (stated purity $99 \%$ ), sodium thiosulphate $\left(\mathrm{Na}_{2} \mathrm{~S}_{2} \mathrm{O}_{3}\right)$ toluene (stated purity $99 \%$ ), diethyl ether (stated purity $\geq 99 \%$ ), ethyl acetate (EtOAc) (stated purity 99\%), n-hexane (stated purity 99\%), sodium hydrogen carbonate $\left(\mathrm{NaHCO}_{3}\right)$ (stated purity $98 \%$ ), $\mathrm{Na}_{2} \mathrm{SO}_{4}$ (stated purity $98 \%$ ), styrene, $\mathrm{ABIN}$, toluene were purchased from Merck A.G and Sigma-Aldrich. The materials and chemicals were used without any further purification.

\subsection{Instrumentation}

All ${ }^{1} \mathrm{H}$ NMR and ${ }^{13} \mathrm{C}$ NMR spectra were recorded using a Varian AS 400+ Mercury FT NMR spectrometer at ambient temperature. FTIR spectra were recorded on a Perkin Elmer 100 FTIR spectrometer. The test wavenumber range of FTIR spectra were $400-4000 \mathrm{~cm}^{-1}$. Optical rotations were determined using a Rudolph Research Analytical Autopol I automatic polarimeter with a wavelength of $589 \mathrm{~nm}$. The concentration ' $c$ ' has units of $g / 100 \mathrm{~mL}$. Elemental analyses were performed on a Perkin-Elmer PE 2400 elemental analyzer. TLC and column chromatography were performed on precoated aluminum plates (Merck 5554) and silica gel G-60 (Merck 7734), respectively.

The TG (Thermogravimetric Analysis) curves were recorded using a Perkin Elmer, Diamond TG/DTA. The samples were heated under $\mathrm{a}_{2}$ atmosphere over a temperature range of 30 to $600^{\circ} \mathrm{C}$ with a heating rate of $10^{\circ} \mathrm{C} \mathrm{min}^{-1}$. The weight loss (TG curve) and its first derivative according to the temperature (DTG curve) were recorded simultaneously.

Molecular weights were determined by a gel permeation chromatography (GPC), viscotek GPC(UK)-max an instrument Autosampler system, consisting of a pump, three visco GEL GPC columns (G2000HHR, G3000HHR and G4000HHR) a viscotek UVdetector and a viscotek differential refractive index (RI) detector with a THF flow rate of $1.0 \mathrm{~mL} / \mathrm{min}$ at $30^{\circ} \mathrm{C}$ were employed.

\subsection{Synthesis of the 5,6-dideoxy-1,2-0-(R)- trichloroethylidene-a-D-xylo-hekso-5-enofuranose (1)}

A solution of $\alpha$-chloralose $(3.1 \mathrm{~g}, 10 \mathrm{mmol})$, triphenylphosphine (TPP) $(10.8 \mathrm{~g}, 40 \mathrm{mmol})$ and imidazole $(3.1 \mathrm{~g}, 10 \mathrm{mmol})$ in dry toluene $(100 \mathrm{~mL})$ was stirred and warmed to $50{ }^{\circ} \mathrm{C}$. Iodine $(10.2 \mathrm{~g}, 40 \mathrm{mmol})$ was added to above reaction mixture in small lots during $30 \mathrm{~min}$ with the temperature of the reactants being maintained aproximetly $60{ }^{\circ} \mathrm{C}$. The reaction mixture was heated 
to reflux for $4 \mathrm{~h}$, cooled room temperature and solvent removed on a rotary evaporator to produce a dark brown syrupy. The purification of the residue is well documented in the literature ${ }^{[60]}$. After this process, the white crystal of the title product was synthesized $\% 86$ yield $(2.4 \mathrm{~g})$. m.p. $102-103{ }^{\circ} \mathrm{C},[\alpha]^{23}{ }_{\mathrm{D}}-14.3\left(c\right.$ 0.7, MeOH). ${ }^{1} \mathrm{H}$ NMR (DMSO, $400 \mathrm{MHz}): \delta 6.05\left(\mathrm{~d}, 1 \mathrm{H}, J_{1,2}=4.0 \mathrm{~Hz}, \mathrm{H}-1\right)$, $5.85(\mathrm{~m}, 1 \mathrm{H}, \mathrm{H}-5), 5.41\left(\mathrm{~s}, 1 \mathrm{H}, \mathrm{HCCl}_{3}\right), 5.34\left(\mathrm{dd}, 1 \mathrm{H}, J_{6 \mathrm{a}, 6 \mathrm{~b}}=0.8\right.$, $\left.J_{5,6 \mathrm{a}}=16.8 \mathrm{~Hz}, \mathrm{H}-6 \mathrm{a}\right), 5.23$ (dd, $J_{6 \mathrm{a}, 6 \mathrm{~b}}=0.8, J_{5,6 \mathrm{~b}}=14.8 \mathrm{~Hz}$, $\mathrm{H}-6 \mathrm{~b}), 4.79$ (dd, $\left.1 \mathrm{H}, J_{4,5}=2.8 \mathrm{~Hz}, J_{3,4}=3.2 \mathrm{~Hz}, \mathrm{H}-4\right)$, $4.51\left(\mathrm{~d}, 1 \mathrm{H}, J_{1,2}=4.0 \mathrm{~Hz}, \mathrm{H}-2\right), 4.07$ (t, $\left.1 \mathrm{H}, J_{3,4}=3.2 \mathrm{~Hz}, \mathrm{H}-3\right)$, 2.50 (br s, $1 \mathrm{H}, \mathrm{OH}) .{ }^{13} \mathrm{C}$ NMR: 133.3 (C-5), 119.2 (C-6), 106.2, $105.7\left(\mathrm{HC}-\mathrm{CCl}_{3}, \mathrm{C}-1\right), 97.6\left(\mathrm{HC}^{-\mathrm{CCl}_{3}}\right), 87.8,83.7$, 75.2(C-2, C-3, C-4).

Anal. Calc. for $\mathrm{C}_{8} \mathrm{H}_{9} \mathrm{Cl}_{3} \mathrm{O}_{4}: \mathrm{C}, 34.88 ; \mathrm{H}, 3.29$. Found: C, 34.55; H, 3.34.

\subsection{Synthesis of the new glyco-polymer (PSVTEG) (2) from vinyl (hydroxyl) furan monomer (1)}

The new copolymer (PSVTEG) (2) from vinyl (hydroxyl) furan monomer (1) $(2.4 \mathrm{~g}, 8,7 \mathrm{mmol})$ and styrene $(1 \mathrm{~mL}, 8,7 \mathrm{mmol})$ (1:1 mol monomer rate) were obtained through a conventional free radical polymerization using 2,2-azobisisobutyronitrile (AIBN) (2\%, based on the total weight of the monomer) as initiator in $10 \mathrm{~mL}$ of toluene at $70{ }^{\circ} \mathrm{C}$ in an all glass Schlenk flask under inert atmosphere. After 24 hours, copolymer $\mathbf{2}$ was obtained with approximetly $90 \%$ conversion. The resulting polymer was precipitated in methanol and dried under vacuum at $40{ }^{\circ} \mathrm{C}$ for overnight. The polymer was then characterized using FTIR and NMR spectroscopy. The synthetic route is presented in Scheme 2. The apparent activation energies for the main degradation stage of the copolymer were calculated from the TG data by using Flynn-Wall-Ozawa (FWO) and Coats-Redfern methods. The activation energies calculated by these methods were found to be $159.0 \pm 3 \mathrm{kj} / \mathrm{mol}$ and $159.2 \pm 3 \mathrm{kj} / \mathrm{mol}$, respectively. ${ }^{1} \mathrm{H} \mathrm{NMR}$ (DMSO, $400 \mathrm{MHz}$ ): $\delta 7.05-6.55(\mathrm{~d}, 5 \mathrm{H}$, aromatic $\mathrm{H}), 6.05\left(\mathrm{~d}, 1 \mathrm{H}, J_{12}=4.0 \mathrm{~Hz}, \mathrm{H}-1\right)$, 5.40 (s, $\left.1 \mathrm{H}, \mathrm{HCCl}_{3}\right), 4.78$ (dd, 1H, H-4), 4.52 (d, 1H, H-2), 4.10 (t, 1H, H-3), 2.62 (m, 1H, CH-), 2.50 (br s, 1H, OH), 1.62-1.25 (m, 5H, $\left.\mathrm{CH}_{2}-, \mathrm{CH}-\right) .{ }^{13} \mathrm{CNMR}$ : 142.0-128.2 (aromatic carbons), 106.2, 105.7 ( $\left.\mathrm{HC}-\mathrm{CCl}_{3}, \mathrm{C}-1\right), 97.6\left(\mathrm{HC}_{-} \mathrm{CCl}_{3}\right)$, 87.8, 83.7, 75.2(C-2, C-3, C-4), 40.4-21.6 (alifatic carbons).

\section{Results and Discussion}

\subsection{Characterization Studies}

\subsubsection{The FTIR spectra of the monomer 1 and copolymer PSVTEG (2)}

The FTIR spectra of compound $\mathbf{1}$ and copolymer PSVTEG (2) are shown in Figure 1. The peak assignments in the FTIR spectrum of compound $\mathbf{1}$ are as follows: $\mathrm{C}-\mathrm{H}$ in $\mathrm{CH}_{3}$ and $\mathrm{C}-\mathrm{H}$ in $\mathrm{CH}_{2}$ at $2925 \mathrm{~cm}^{-1}$; vinyl $\mathrm{C}=\mathrm{CH}_{2}$ at $1505 \mathrm{~cm}^{-1}$; $\mathrm{C}-\mathrm{O}-\mathrm{C}$ peak in the sugar ring at $1162 \mathrm{~cm}^{-1}$; $\mathrm{C}-\mathrm{Cl}$ peaks of trichloroethylidine protective group at 854 and $823 \mathrm{~cm}^{-1}$. Finally, the absorption band at $3294 \mathrm{~cm}^{-1}$ corresponds to the presence of the $\mathrm{C}-3 \mathrm{OH}$ group.

The FTIR spectrum of copolymer 2 (Figure 1) is as follows: $\mathrm{C}-\mathrm{H}$ in $\mathrm{CH}_{3}$ and $\mathrm{C}-\mathrm{H}$ in $\mathrm{CH}_{2}$ at $2800-3000 \mathrm{~cm}^{-1}$; $\mathrm{C}=\mathrm{C}$ double bond peaks in the benzene ring at 1493 and $1452 \mathrm{~cm}^{-1}$;
$\mathrm{C}-\mathrm{O}-\mathrm{C}$ peak in the sugar ring at $1107 \mathrm{~cm}^{-1}$; $\mathrm{C}-\mathrm{Cl}$ peaks of trichloroethylidine protective group at 832 and $812 \mathrm{~cm}^{-1}$. Finally, the absorption band at $3440 \mathrm{~cm}^{-1}$ corresponds to the presence of the $\mathrm{C}-3 \mathrm{OH}$ group. Instead of the vinyl $\mathrm{C}=\mathrm{CH}_{2}$ at $1505 \mathrm{~cm}^{-1}$ peak observed in the FTIR spectrum of new vinyl (hydroxyl) furan monomer (1), the mono substitute benzene ring peak at $698 \mathrm{~cm}^{-1}$ was observed in the FTIR spectrum of the copolymer PSVTEG (2).

\subsubsection{The ${ }^{1} \mathrm{H}$ and ${ }^{13} \mathrm{C}$ NMR spectra of the monomer 1 and copolymer PSVTEG (2)}

In the ${ }^{1} \mathrm{H}-\mathrm{NMR}$ spectrum of the monomer 1 the anomeric $\mathrm{H}-1$ proton usually appears at a low field and is a very characteristic and distinct signal. Two doublets are observed in this ${ }^{1} \mathrm{H}-\mathrm{NMR}$ spectrum. One is the $\mathrm{H}-1$ doublet at $\delta 6.05$ and another is the $\mathrm{H}-2$ doublet at $\delta 4.51$. The coupling constant between $\mathrm{H}-1$ and $\mathrm{H}-2$ is $4.0 \mathrm{~Hz}$ which is typical for an $\alpha$-D-furanose derivative. Due to the twisted conformation of the furanose rings, the dihedral angle between the $\mathrm{H}-2$ and $\mathrm{H}-3$ protons are usually $90^{\circ}$. Hence, in the ${ }^{1} \mathrm{H}$ NMR spectrum of compound 1, the coupling constant between $\mathrm{H}-2$ and $\mathrm{H}-3$ is $0 \mathrm{~Hz}$. The $\mathrm{H}-5$ protons give a complex multiplet at $\delta 5.85$. One of the H-6 signals obtained is H-6a which is resolved into add at $\delta 4.34$ with one of the coupling constant between H-6a and H-5 of $16.8 \mathrm{~Hz}$. The another of the coupling constant between $\mathrm{H}-6 \mathrm{a}$ and $\mathrm{H}-6 \mathrm{~b}$ of is $0.8 \mathrm{~Hz}$ and $\mathrm{H}-6 \mathrm{~b}$ signal is observed at $\delta 5.23$ with one of the coupling constant between $\mathrm{H}-5$ and $\mathrm{H}-6 \mathrm{~b}$ of $14.8 \mathrm{H}$. The $\mathrm{H}-4$ signals are resolved giving a triplet signal at $\delta 4.79$ with a coupling constant between $\mathrm{H}-4$ and $\mathrm{H}-5$ of 3.2 The H-3 signals are resolved giving a triplet signal at $\delta 4.07$ with a coupling constant between H-3 and H-4 of $3.2 \mathrm{~Hz}$. The hydroxyl proton is resolved giving a br singlet at $\delta 2.50$. Finally, the trichloroethylidene acetal proton $\left(\mathrm{HCCl}_{3}\right)$ gives a signal at $\delta 5.41$. Also, the ${ }^{13} \mathrm{C}$ NMR peak performance of the monomer 1 was described and similarly, the expected indications were observed. In the ${ }^{13} \mathrm{C}$ NMR spectrum of monomer 1, the peaks at 133.3 and $119.2 \mathrm{ppm}$ (C-5 and C-6) assigned thevinyl carbon. In addition, trichloroethylidene acetal carbon $\left(\mathrm{HC}-\mathrm{CCl}_{3}\right)$ was observed at $106.2 \mathrm{ppm} .{ }^{13} \mathrm{C} \mathrm{NMR}$ peak of the sugar moiety for the monomer 1 was observed as predicted from $\mathrm{C}-1$ at $105.7 \mathrm{ppm}$.

In the ${ }^{1} \mathrm{H}$ NMR spectrum of the copolymer PSVTEG (2), disappearance of characteristic vinyl peaks for the the monomer is observed. And also, the acetal proton, the

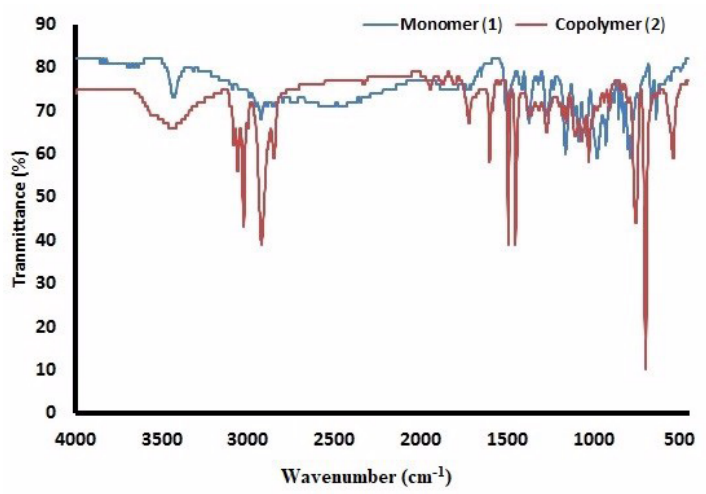

Figure 1. The FTIR spectra of new vinyl (hydroxyl) furan monomer (1) and the copolymer PSVTEG (2). 
trichloroethylidene acetal proton $\left(\mathrm{HCCl}_{3}\right)$ and other sugar protons give a signal at $\delta 6.05,5.40,4.78-4.10$, respectively. Besides, the appearance of the aromatic proton peaks for the styrene are observed as multiplet at $\delta 7.05$ and 6.55 in the ${ }^{1} \mathrm{H}$ NMR spectrum of the copolymer PSVTEG (2).

In the case of the polymer, it is observed that alkyl group carbon peaks of the copolymer PSVTEG (2) appeared in the range from 40.4 to $21.6 \mathrm{ppm}$ in the ${ }^{13} \mathrm{C}$ NMR spectrum. Therefore, vinyl carbons of glycopolymer shifted to a higher field as a result of increased electron intensity. ${ }^{13} \mathrm{C}$ NMR peaks of the sugar moiety of the copolymer $\mathbf{2}$ are observed from $\mathrm{C}-1$ to $\mathrm{C}-4$, as predicted. Furhermore, the appearance of the aromatic carbon peaks for the styrene appeared in the range from 142.0 to128.2 $\mathrm{ppm}$ in ${ }^{13} \mathrm{C}$ NMR spectrum of the glycopolymer $\mathbf{2}$.

\subsection{Thermogravimetric analysis of the copolymer PSVTEG (2)}

Thermal properties of glycopolymer (PSVTEG) (2) were investigated by TG and DTG under argon atmosphere over a temperature range 30 to $600{ }^{\circ} \mathrm{C}$ with a heating rate of $10^{\circ} \mathrm{C} / \mathrm{min}$. The thermogram of the glycopolymer (PSVTEG) (2) shows two decomposition stages (Figure 2). The thermal decomposition in the first stage is in a weight loss of nearly $10 \%$. The main degrading process involving random scission starts around $350{ }^{\circ} \mathrm{C}$.

According to the literature data, using the TG/DTG-DTA-FTIR analysis, the following releasing gases after pyrolysis could be seen u.a: $\mathrm{H}_{2} \mathrm{O}, \mathrm{C}=\mathrm{O}, \mathrm{CH}_{4}, \mathrm{C}_{2} \mathrm{H}_{2}$, and $\mathrm{C}_{2} \mathrm{H}_{4} \mathrm{O}_{2}^{[6]]}$. The degradation reactions began at the temperature of circa $200{ }^{\circ} \mathrm{C}$, when the thermal condensation between hydroxyl groups of copolymer chains started the formation of ether fragments, and the release of water molecules was obtained. When dehydratation was located in the neighborhood of itself, hydroxyl groups in the glycosidic ring cause the formation of the $\mathrm{C}=\mathrm{C}$ bond or degradation of the glycosidic ring. All of aldehyde groups were formed at the same time as terminal groups, while the monosaccharide ring was damaged. The main degradation reactions began at the temperature of circa $350{ }^{\circ} \mathrm{C}$, aromatic rings such as substituted benzene and furan structures with groups such as $-\mathrm{CH}_{2}-$ or $-\mathrm{CH}_{2}-\mathrm{O}-\mathrm{CH}_{2}-$ as main binders between the aromatic rings could be seen ${ }^{[62]}$.

\subsection{Thermal degradation kinetics of the copolymer (PSVTEG) (2)}

The glycopolymer (PSVTEG) (2) was heated thermogravimetrically under various heating rates such as $5,10,15$, and $20{ }^{\circ} \mathrm{C} / \mathrm{min}$ in a temperature range of 30 to $600{ }^{\circ} \mathrm{C}$ to determine their thermal degradation mechanisms and the activation energies. The TG curves obtained for the copolymer is shown in Figure 3 and 4, respectively. The individual degradation behavior of the glycopolymer (PSVTEG) (2) was analogous at all heating rates as seen from these figures. The apparent activation energies and thermal degradation models for the copolymer was estimated by FWO and Coats-Redfern.

The thermal degradation mechanism of the copolymer (PSVTEG) (2) for the main degradation stage is confirmed by comparing the mean activation energy value $\left(\mathrm{E}_{\mathrm{FWO}}\right)$

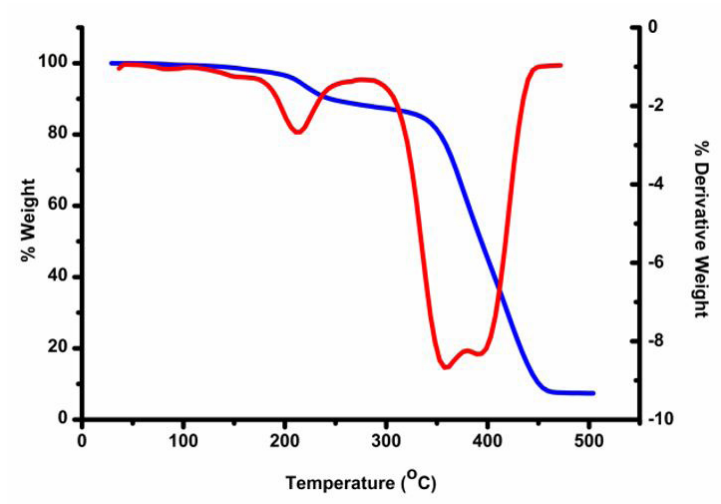

Figure 2. DTG curves of glycopolymer PSVTEG (2).

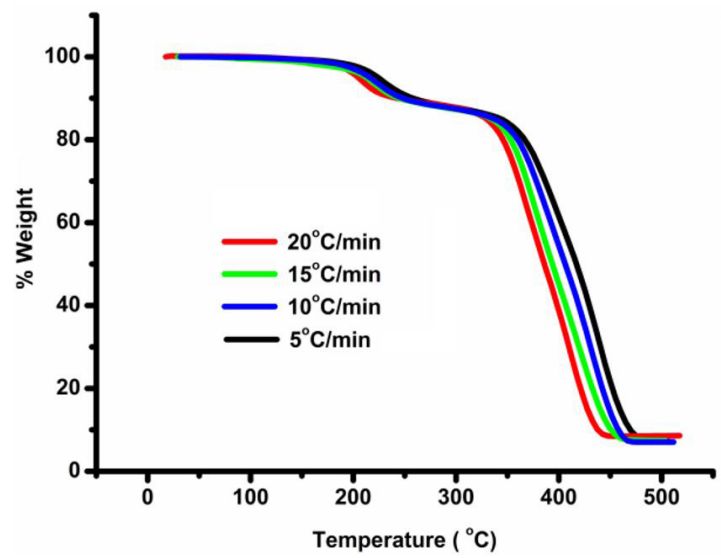

Figure 3. TG curves of glycopolymer PSVTEG (2).

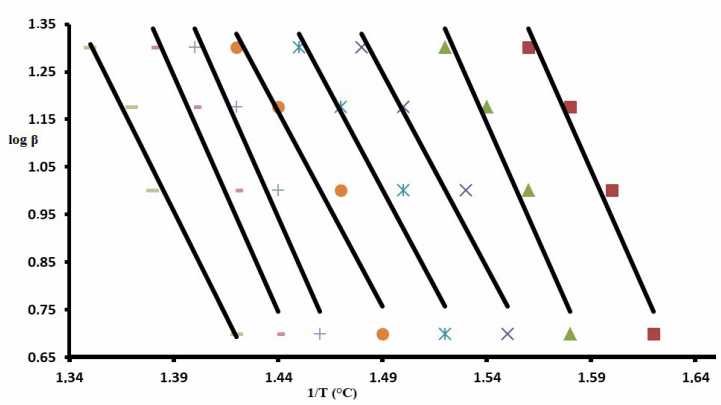

Figure 4. FWO plots for the thermal decomposition of glycopolymer PSVTEG (2) at varying conversion in $\mathrm{N}_{2}$.

with those calculated by the Coats-Redfern method for different models. The activation energies and correlations obtained from Coats-Redfern method at different heating rates are represented in Table 1 . The $\mathrm{E}$ calculated from the $\boldsymbol{F}_{3}$ model is nearly the same with $\mathrm{E}_{\mathrm{FWO}}$ for PSVTEG (2) and found as $159.0 \pm 3 \mathrm{~kJ} / \mathrm{mol}$ leading to a conclusion that the most probable mechanism for the thermal degradation of PSVTEG (2) is the third-order. Therefore, the calculated activation energy indicates that the main degradation stage is a nonspontaneous process (integral form $1 /(1-\alpha)^{2}$ for $F_{3}$ ). In literature, the activation energry value of polystrene homopolymer and vinyl sugar- carrying copolymer viz., 
Table 1. Algebraic expressions of $f(\alpha)$ and $g(\alpha)$ for the reaction models considered in the present work.

\begin{tabular}{|c|c|c|c|}
\hline Symbol & Reaction model & $f(\alpha)$ & $\mathrm{g}(\alpha)$ \\
\hline \multicolumn{4}{|c|}{ Sigmoidal curves } \\
\hline \multirow[t]{2}{*}{ A2 } & Avrami-Erofěev $(\mathrm{n}=2)$ & $2(1-\alpha)[-\ln (1-\alpha)]^{1 / 2}$ & {$[-\ln (1-\alpha)]^{1 / 2}$} \\
\hline & (Nucleation and growth) & & \\
\hline \multirow[t]{2}{*}{$\mathbf{A 3}$} & Avrami-Erofěev $(\mathrm{n}=3)$ & $3(1-\alpha)[-\ln (1-\alpha)]^{2 / 3}$ & {$[-\ln (1-\alpha)]^{1 / 3}$} \\
\hline & (Nucleation and growth) & & \\
\hline \multirow[t]{2}{*}{ A4 } & Avrami-Erofěev $(n=4)$ & $4(1-\alpha)[-\ln (1-\alpha)]^{3 / 4}$ & {$[-\ln (1-\alpha)]^{1 / 4}$} \\
\hline & (Nucleation and growth) & & \\
\hline \multirow[t]{2}{*}{ An } & Avrami-Erofěev $(n=n)$ & $\mathrm{n}(1-\alpha)[-\ln (1-\alpha)]^{(\mathrm{n}-1) / \mathrm{n}}$ & {$[-\ln (1-\alpha)]^{1 / n}$} \\
\hline & (Nucleation and growth) & & \\
\hline \multicolumn{4}{|c|}{ Deceleration curves } \\
\hline \multirow[t]{3}{*}{$\mathbf{R 1}$} & Zero-order (Polany-Winger equation) & 1 & $\alpha$ \\
\hline & Phase-boundary controlled reaction & & \\
\hline & (one dimensional movement) & & \\
\hline $\mathbf{R 2}$ & Phase-boundary controlled reaction (contracting area, i.e., bidimensional shape) & $2(1-\alpha)^{1 / 2}$ & {$\left[1-(1-\alpha)^{1 / 2}\right]$} \\
\hline R3 & Phase-boundary controlled reaction (contracting area, i.e., bidimensional shape) & $3(1-\alpha)^{2 / 3}$ & {$\left[1-(1-\alpha)^{1 / 3}\right]$} \\
\hline \multirow[t]{2}{*}{ F1 } & First-order (Mampel) & $(1-\alpha)$ & $-\ln (1-\alpha)$ \\
\hline & (Random nucleation with two nucleus on the individual particle) & & \\
\hline \multirow[t]{2}{*}{ F2 } & Second-order & $(1-\alpha)^{2}$ & $1 /(1-\alpha)$ \\
\hline & (Random nucleation with two nucleus on the individual particle) & & \\
\hline \multirow[t]{2}{*}{$\mathbf{F 3}$} & Third-order & $(1-\alpha)^{3}$ & $1 /(1-\alpha)^{2}$ \\
\hline & (Random nucleation with two nucleus on the individual particle) & & \\
\hline D1 & One-dimensional diffusion & $1 / 2 \alpha$ & $\alpha^{2}$ \\
\hline D2 & Two-dimensional diffusion (bidimensional particle shape) Valensi equation & $1 /[-\ln (1-\alpha)]$ & $(1-\alpha) \ln (1-\alpha)+\alpha$ \\
\hline D3 & Three-dimensional diffusion (tridimensional particle shape) Jander equation & $3(1-\alpha)^{1 / 3} / 2\left[(1-\alpha)^{-1 / 3}-1\right]$ & {$\left[1-(1-\alpha)^{1 / 3}\right]^{2}$} \\
\hline D4 & Three-dimensional diffusion (tridimensional particle shape) Ginstling-Brounshtein & $3 / 2\left[(1-\alpha)^{-1 / 3}-1\right]$ & $(1-2 \alpha / 3)-(1-\alpha)^{2 / 3}$ \\
\hline
\end{tabular}

poly (galactomethacrylate-co-styrene) $(\mathrm{P}(\mathrm{gm}-\mathrm{co}-\mathrm{st}))$ were stated as circa $50 \pm 5 \mathrm{~kJ} / \mathrm{mol}$ and $185 \pm 28 \mathrm{~kJ} / \mathrm{mol}$, respectively ${ }^{[63,64]}$. In addition, Pană et al. have indicated the avarage activation energy value of a glycopolymer derived from a D-mannose oligomer with maleic backbone and 2-hydroxypropyl acrylate inside as $105.98 \mathrm{~kJ} / \mathrm{mol}$ by using Flynn-Wall-Ozawa method ${ }^{[65]}$. When these values in the literature was compared with the activation energy value of the copolymer PSVTEG (2), it was concluded that the copolymer was a sugar-based styrene copolymer.

\subsection{Molecular weight study of the copolymer (PSVTEG) (2)}

The number average molecular weight $(M \mathrm{n})$, weight average molecular weight $(M \mathrm{w})$ and polydispersity index (PDI) for glyco-polymer (PSVTEG) (2) was analysed by GPC. The number average molecular weight $(\mathrm{Mn})$, mass average molecular weight $(\mathrm{Mw})$ and polydispersity index (PDI) of glyco-polymer (PSVTEG) (2) were found to be $14000 \mathrm{~g} / \mathrm{mol}, 18900 \mathrm{~g} / \mathrm{mol}$ and 1.35 , respectively.

\section{Conclusions}

A new carbohydrate-based the copolymer of styrene (2) from vinyl (hydroxyl) furan monomer (1) were synthesized by a conventional free radical polymerization reaction using AIBN as an initiator in toluene. The thermal degradation of the copolymer of styrene (2) from vinyl (hydroxyl) furan monomer (1) under nitrogen atmosphere is a one-stage reaction. The thermal degradation kinetics of the compounds was evaluated using the Flynn-Wall-Ozawa (FWO) and CoatsRedfern methods. The activation energies calculated by these methods were found to be $159.0 \pm 3 \mathrm{kj} / \mathrm{mol}$ and $159.2 \pm 3 \mathrm{kj} / \mathrm{mol}$, respectively. Consequently, the calculated activation energy shows that the main degradation stage is a nonspontaneous process (integral form $1 /(1-\alpha)^{2}$ for $\mathrm{F}_{3}$ ).

\section{Acknowledgements}

I would like to Ege University for financial support of this work (2017 FEN 077).

\section{References}

1. Pearson, S., Chen, G., \& Stenzel, M. H. (2011) Synthesis of Glycopolymers. In R. Narain (Ed.), Engineered carbohydratebased materials for biomedical applications: polymers, surfaces, dendrimers, nanoparticles, and hydrogels (pp. 1-118). Hoboken: John Wiley \& Sons, Inc.

2. Louwrier,A. (1998). Industrial products: the return to carbohydrate - Based industries. Biotechnology and Applied Biochemistry, 27(1), 1-8. http://dx.doi.org/10.1111/j.1470-8744.1998.tb01368.x.

3. Singh, R., Bhattacharya, B., Rhee, H. W., \& Singh, P. K. (2015). Solid gellan gum polymer electrolyte for energy application. International Journal of Hydrogen Energy, 40(30), 9365-9372. http://dx.doi.org/10.1016/j.ijhydene.2015.05.084.

4. Methven, J. M. (1991). Polymeric materials from renewable resources. Rapra Review Reports, 4(1), 1-134. http://dx.doi. org/10.1080/15583720701834133.

5. Borges, M.R., Dos Sandos, J.A., Vieira, M., \& Balaban R. (2009). Polymerization of a water soluble glucose vinyl ester monomer 
with tensoactive properties synthesized by enzymatic catalyst. Materials Science and Engineering C, 29(2), 519-523. http:// dx.doi.org/10.1016/j.msec.2008.09.013.

6. Varma, A.J., Kennedy, J.F., \& Galgali, P. (2004) Synthetic polymers functionalized by carbohydrates: Areview. Carbohydrate Polymers, 56(4), 429-445. http://dx.doi.org/10.1016/j.carbpol.2004.03.007.

7. Bertini, V., Pocci, M., Alfei, S., Idini, B., \& Lucchesini, F. (2007). Synthesis of crosslinked nanostructured saccharidic vinyl copolymers and their functionalization. Tetrahedron, 63(47), 11672-11680. http://dx.doi.org/10.1016/j.tet.2007.08.106.

8. Sanchez-Chaves, M., Ruiz, C., Cerrada, M. L., \& Fernandez-Garcia, M. (2008). Novel glycopolymers containing aminosaccharide pendant groups by chemical modification of ethylene-vinyl alcohol copolymers. Polymer, 49(12), 2801-2807. http://dx.doi. org/10.1016/j.polymer.2008.04.047.

9. Li, S., Jasim, A., Zhao, W., Fu, L., Ullah, M. W., Shi, Z., \& Yang, G. (2018). Fabrication of pH-electroactive bacterial cellulose/ polyaniline hydrogel for the development of a controlled drug release system. ES Materials \& Manufacturing, 1, 41-49. http:// dx.doi.org/10.30919/esmm5f120.

10. Du, W., Wang, X., Zhan, J., Sun, X., Kang, L., Jiang, F., Zhang, X., Shao, Q., Dong, M., Liu, H., Murugadoss, V., \& Guo, Z. (2019) Biological cell template synthesis of nitrogen-doped porous hollow carbon spheres/MnO2 composites for high-performance asymmetric supercapacitors. Electrochimica Acta, 296, 907-915. http://dx.doi.org/10.1016/j.electacta.2018.11.074.

11. Wang, W., Hao, X., Chen, S., Yang, Z., Wang, C., Yan, R., Zhang, X., Liuc, H., Shaod, Q., \& Guo, Z. (2018) pH-responsive Capsaicin@chitosan nanocapsules for antibiofouling in marine applications. Polymer, 158, 223-230. http://dx.doi.org/10.1016/j. polymer.2018.10.067.

12. Kashfipour, M. A., Mehra, N., Dent, R. S., \& Zhu, J. (2020). Regulating intermolecular chain interaction of biopolymer with natural polyol for flexible, optically transparent and thermally conductive hybrids. Engineered Science, 8, 11-18. http://dx.doi. org/10.30919/es8d508.

13. Lichtenthaler, F. W., \& Peters, S. C. R. (2004). Carbohydrates as green raw materials for the chemical industry. Chimie, 7(2), 65-90. http://dx.doi.org/10.1016/j.crci.2004.02.002.

14. Sampath, C. A., \& Edward, T. (2007). Glycosylated polyacrylate nanoparticles by emulsion polymerization. Carbohydrate Polymers, 70(1), 32-37. http://dx.doi.org/10.1016/j.carbpol.2007.02.027. PMid:18677404.

15. Stanek, L. G., Heilmann, S. M., \& Gleason, W. B. (2006). Preparation and copolymerization of a novel carbohydrate containing monomer. Carbohydrate Polymers, 65(4), 552-556. http://dx.doi. org/10.1016/j.carbpol.2006.01.021.

16. Vert, M. (2007). Polymeric biomaterials: Strategies of the past vs. strategies of the future. Progress in Polymer Science, 32(8-9), 755-761. http://dx.doi.org/10.1016/j.progpolymsci.2007.05.006.

17. Varma, A. J., Kennedy, J. F., \& Galgali, P. (2004). Synthetic polymers functionalized by carbohydrates. Carbohydrate Polymers, 56(4), 429-445. http://dx.doi.org/10.1016/j.carbpol.2004.03.007.

18. Ma,Z., \& Zhu, X.X. (2019). Copolymers containing carbohydrates and other biomolecules: Design, synthesis and applications. Journal of Materials Chemistry. B, Materials for Biology and Medicine, 7(9), 1361-1378. http://dx.doi.org/10.1039/C8TB03162B. PMid:32255007.

19. Roy, R., Tropper, F. D., \& Romanowska, A. (1992). New strategy in glycopolymer syntheses. Preparation of antigenic water-soluble poly(acrylamideco-p-acrylamido-phenyl beta lactoside). Bioconjugate Chemistry, 3(3), 256-261. http://dx.doi.org/10.1021/bc00015a009. PMid:1520730.

20. Okada, M. (1992). Molecular design and syntheses of glycopolymers. Progress in Polymer Science, 26(1), 67-104. http://dx.doi. org/10.1016/S0079-6700(00)00038-1.
21. Haddleton, D. M., Edmonds, R., Heming, A. M., Kelly, E. J., \& Kukulj, D. (1999). Atom transfer polymerisation with glucose and cholesterol derived initiators. New Journal of Chemistry, 23(5), 477-479. http://dx.doi.org/10.1039/a901929d.

22. Ohno, K., Tsujii, Y., \& Fukuda, T. (1998). Synthesis of a well-defined glycopolymer by atom transfer radical polymerization. Journal of Polymer Science. Part A, Polymer Chemistry, 36(14), 2473-2481. http://dx.doi.org/10.1002/(SICI)1099-0518(199810)36:14<2473::AIDPOLA5 $>3.0 . \mathrm{CO} ; 2-\mathrm{U}$.

23. Ting, S. R. S., Granville, A. M., Quémener, D., Davis, T. P., Stenzel, M. H., \& Barner-Kowollik, C. (2007). RAFT Chemistry and Huisgen 1,3-dipolar cycloaddition:a route to block copolymers of vinyl acetate and 6-O-methacryloylmannose. Australian Journal of Chemistry, 60(6), 405-409. http://dx.doi.org/10.1071/CH07089.

24. Ladmiral, V., Melia, E., \& Haddleton, D. M. (2004). Synthetic glycopolymers: An overview. European Polymer Journal, 40(3), 431-449. http://dx.doi.org/10.1016/j.eurpolymj.2003.10.019.

25. Roy, R. (1996). Blue-prints, synthesis and applications of glycopolymers. Trends in Glycoscience and Glycotechnology, 8(40), 79-99. http://dx.doi.org/10.4052/tigg.8.79.

26. Deppe, O., Glümer, A., Yu, S., \& Buchholz, K. (2004). Synthesis and co-polymerization of an unsaturated 1,5-anhydro-D-fructose derivative. Carbohydrate Research, 339(12), 2077-2082. http:// dx.doi.org/10.1016/j.carres.2004.06.007. PMid:15280052.

27. Ştefan, L. N., Pana, A. M., Pascariu, M. C., Şişu, E., Bandur, G., $\&$ Rusnac, L. M. (2011). Synthesis and characterization of a new methacrylic glycomonomer. Turkish Journal of Chemistry, 35, 757-767. http://dx.doi.org/10.3906/kim-1103-63.

28. Fatma, Ç. T. (2015). Syntheses and characterization of new 3-O-Allyl ether chloralose derivatives. Asian Journal of Chemistry, 27(1), 353-356. http://dx.doi.org/10.14233/ajchem.2015.17975.

29. Wulff, G., Schmid, J., \& Venhoff, T. (1996). The synthesis of polymerizable vinyl sugars. Macromolecular Chemistry and Physics, 197(1), 259-274. http://dx.doi.org/10.1002/macp.1996.021970120.

30. Klein, J., Herzog, D., \& Hajibegli, A. (1985). Poly vinylsaccharides. Synthesis and characterization of polyvinylsaccarides of the urea type. Macromolecular Rapid Communications, 10(12), 629-636. http://dx.doi.org/10.1002/marc.1989.030101203.

31. Klein, J., \& Blumenberg, K. (1986). Poly(vinyl saccharide)s, $3 \uparrow$. Synthesis and cationic polymerization of 6-O-vinyl-1,2:3,4di-O-isopropylidene-D-galactopyranose. Macromolecular Rapid Communications, 6(10), 621-625. http://dx.doi.org/10.1002/ marc.1986.030071001.

32. Nakamae, K., Miyata, T., Otsuki, N., Okumura, M., \& Kinomura, K. (1994). Surface characterizations of copolymer films with pendant monosaccharides. Macromolecular Chemistry and Physics, 195(6), 1953-1963. http://dx.doi.org/10.1002/macp.1994.021950606.

33. Nakamae, K., Miyata, T., Ootsuki, N., Okumura, M., \& Kinomura, K. (1994). Surface studies on copolymers having pendant monosaccharides. Macromolecular Chemistry and Physics, 195(7), 2663-2675. http://dx.doi.org/10.1002/macp.1994.021950733.

34. Wulff, G., \& Clarkson, G. (1994). On the synthesis of $C$-glycosyl compounds containing double bonds without the use of protecting groups. Carbohydrate Research, 257(1), 81-95. http://dx.doi. org/10.1016/0008-6215(94)84109-8.

35. Wulff, G., \& Clarkson, G. (1994). New type of polyvinylsaccharides with N,N-dimethyl barbituric acid as a linker between sugar and styrene residue. Macromolecular Chemistry and Physics, 195(7), 2603-2610. http://dx.doi.org/10.1002/macp.1994.021950728.

36. Wulff, G., Schmid, J., \& Venhoff, T. (1996). The synthesis of polymerizable vinyl sugars. Macromolecular Chemistry and Physics, 197(1), 259-274. http://dx.doi.org/10.1002/macp.1996.021970120.

37. Wulff, G., Schmid, J., \& Venhoff, T. (1996). The preparation of new types of polymerizable vinyl sugars with $\mathrm{CC}$ bonds between sugar and double bond. Macromolecular Chemistry and Physics, 197(4), 1285-1299. http://dx.doi.org/10.1002/macp.1996.021970409. 
38. Wulff, G., Zhu, L., \& Schmidt, H. (1997). Investigations on surface-modified bulk polymers. 1.Copolymers of styrene with a styrene moiety containing a sugar monomer. Macromolecules, 30(16), 4533-4539. http://dx.doi.org/10.1021/ma961890z.

39. Heffter, A. (1889). Ueber die Einwirkung von Chloral auf Glucose. Berichte der Deutschen Chemischen Gesellschaft, 22(1), 10501051. http://dx.doi.org/10.1002/cber.188902201230.

40. Hanriot, M., \& Richet, C. (1983). D'une substance dérivée du chloral ou chloralose, et de ses effets physiologiques et thérapeutiques. Comptes Rendus Hebdomadaires des Séances de l'Académie des Sciences, 116, 63-65.

41. Hanriot, M. (1909). D'une substance dérivée du chloral ou chloralose, et de ses effets physiologiques et thérapeutiques. Annales de Chimie et de Physique, 18, 466-502.

42. Forsen, S., Lindberg, B., Silvander, B. G., Nilsson, B., Selin, K., \& Westerdahl, A. (1965). Trichloroethylidene derivatives of D-glucose. Acta Chemica Scandinavica, 19, 359-369. http:// dx.doi.org/10.3891/acta.chem.scand.19-0359.

43. Yenil, N., Ay, E., Ay, K., Oskay, M., \& Maddaluno, J. (2010). Synthesis and antimicrobialactivities of two novel amino sugars derived from chloraloses. Carbohydrate Research, 345(11), 1617-1621. http://dx.doi.org/10.1016/j.carres.2010.03.043. PMid:20488435.

44. Salman, Y. G., Makinabakan, O., \& Yuceer, L. (1994). Tricyclic orthoester formation from trichloroethylidene acetals of sugars via ketene acetals. Tetrahedron Letters, 35(49), 9233-9236. http:// dx.doi.org/10.1016/0040-4039(94)88475-7.

45. Cetin, F., Yenil, N., \& Yuceer, L. (2004). Stable spiro-endoperoxides by sunlight-mediated photooxygenation of 1,2-O-alkylidene-5(E)eno-5,6,8-trideoxy- $\alpha$-d-xylo-oct-1,4-furano-7-uloses. Carbohydrate Research, 340(17), 2583-2589. http://dx.doi.org/10.1016/j. carres.2005.09.006. PMid:16182263.

46. Telli, F. C., \& Yuceer, L. (2012). Synthesis of new spirodifuranose derivatives by reduction of stable spiro-endoperoxides. Journal of Carbohydrate Chemistry, 31(9), 721-731. http://dx.doi.org/10 .1080/07328303.2012.739229.

47. Telli, F. C., Ay, K., Murat, G., Kok, G., \& Salman, Y. (2013). Acid promoted intramolecular formation of 3,5-anhydro-1,4-furano-7ulose derivatives via the Wittig-cyclization procedure and their antimicrobial properties. Medicinal Chemistry Research, 22(5), 2253-2259. http://dx.doi.org/10.1007/s00044-012-0218-4.

48. Denizaltı, S., Telli, F. C., Yıldıran, S., Salman, A. Y., \& Çetinkaya, B. (2016). The newly synthesized furanoside-based NHC ligands for the arylation of aldehydes. Turkish Journal of Chemistry, 40, 689-697. http://dx.doi.org/10.3906/kim-1603-95.

49. Alkan, S., Telli, F. C., Salman, Y., \& Astley, S. T. (2015). Synthesis of novel schiff base ligands from Gluco- and Galactochloraloses for the $\mathrm{Cu}$ (II) catalysed asymmetric henry reaction. Carbohydrate Research,407,97-103.http://dx.doi.org/10.1016/j.carres.2015.01.023. PMid:25742867.

50. Telli, F. C., Demir, B., Barlas, F. B., Guler, E., Timur, S., \& Salman, Y. (2016). Novel Glyconanoconjugates: Synthesis. Characterization and Bioapplications RCS Advances., 6, 105806-105813. http:// dx.doi.org/10.1039/C6RA21976D.

51. Xie, P., Li, Y., Hou, Q., Sui, K., Liu, C., Fu, X., Zhang, J., Murugadoss, V., Fan, J., Wang, Y., Fan, R., \& Guo, Z. (2020). Tunneling-induced negative permittivity in $\mathrm{Ni} / \mathrm{MnO}$ nanocomposites by a bio-gel derived strategy. Journal of Materials Chemistry C, 8, 3029-3039. http://dx.doi.org/10.1039/ c9tc06378a.

52. Sun, K., Dong, J., Wang, Z., Wang, Z., Fan, G., Hou,Q., An, L., Dong, M., Fan, R., \& Guo, Z. (2019). Tunable Negative Permittivity in Flexible Graphene/PDMS Metacomposites. Journal of Physical
Chemistry C, 123, 23635-23642. http://dx.doi.org/10.1021/acs. jpcc.9b06753.

53. Sun, K., Wang, L., Wang, Z., Wu, X., Fan, G., Wang, Z., Cheng, C., Fan, R., Dong, M., \& Guo, Z. (2019). Flexible silver nanowire/ carbon fiber felt metacomposites with weakly negative permittivity behavior. Physical Chemistry Chemical Physics, 22(9), 5114-5122. http://dx.doi.org/10.1039/C9CP06196G. PMid:32073008.

54. Lee, S., Jin, B.S., \& Lee, J.W. (2006) Thermal degradation kinetics of antimicrobial agent, Poly(hexamethylene guanidine) phosphate. Macromolecular Research, 14, 491-498.

55. Wang, D., Das, A., Leuteritz, A., Boldt, R., Häußler, L., Wagenknecht, U., \& Heinrich, G. (2011). Thermal degradation behaviors of a novel nanocomposite based on polypropylene and Co-Al layered double hydroxide. Polymer Degradation \& Stability, 96(3), 285290. http://dx.doi.org/10.1016/j.polymdegradstab.2010.03.003.

56. Wang, H., Yang, J., Long, S., Wang, X., Yang, Z., \& Li, G. (2004). The thermal degradation of poly(phenylene sulfide sulfone). Polymer Degradation \& Stability, 83(2), 229-235. http://dx.doi. org/10.1016/S0141-3910(03)00266-0.

57. Coats, A. W., \& Redfern, J. P. (1964). Kinetic parameters from thermogravimetric data. Nature, 201(4914), 68-69. http://dx.doi. org/10.1038/201068a0.

58. Flynn, J. H., \& Wall, L. A. (1966). A quick direct method for the determination of activation energy from thermogravimetric data. Journal of Polymer Science. Part B, Polymer Physics, 4(5), 323328. http://dx.doi.org/10.1002/pol.1966.110040504.

59. Ozawa, T. (1965). Anew method of analyzing thermogravimetric data. Bulletin of the Chemical Society of Japan, 38(11), 1881-1886. http://dx.doi.org/10.1246/bcsj.38.1881.

60. Mereyala, H. B., Goud, P. M., Gadikota, R. R., \& Reddy, K. R. (2000). Transformation of terminal diols of cyclic and acyclic saccharides to epoxides and alkenes by reaction with triphenylphosphine, imidazole and iodine. Journal of Carbohydrate Chemistry, 19(9), 1211-1222. http://dx.doi.org/10.1080/07328300008544145.

61. Pigłowska, M., Kurc, B., Rymaniak, L., Lijewski, P., \& Fu'c, P. (2020). Kinetics and thermodynamics of thermal degradation of different starches and estimation the $\mathrm{OH}$ group and $\mathrm{H} 2 \mathrm{O}$ Content on the Surface byTG/DTG-DTA. Polymers, 12(2), 357-361. http:// dx.doi.org/10.3390/polym12020357. PMid:32041286.

62. Yildirim, Y., Dogan, B. S., Muglali, S., Saltan, F., Ozkan, M., \& Akat, H. (2012). Synthesis, characterization, and thermal degradation kinetic of Polystyrene-g-Polycaprolactone. Journal of Applied Polymer Science, 126(4), 1236-1246. http://dx.doi. org/10.1002/app.36888.

63. Funt, J. M., \& Maghill, J. H. (1974). Thermal decomposition of polystyrene: Eflect of molecular weight. Journal of Polymer Science. Polymer Physics Edition, 12(1), 217-220. http://dx.doi. org/10.1002/pol.1974.180120118.

64. Saltan, F., \& Akat, H. (2013). Synthesis and thermal degradation kinetics of D-(+)- GALACTOSE CONTAINING POLYMERS. Polimeros: Ciência e Tecnologia, 23(6), 697-704. http://dx.doi. org/10.4322/polimeros.2014.012.

65. Pană, A. M., Ordodi, V., Rusu, G., Gherman, V., Bandur, G., Rusnac, L. M., \& Dumitrel, G. A. (2020). Biodegradation pattern of glycopolymer based on D-Mannose oligomer and Hydroxypropyl Acrylate. Polymers, 12(3), 704-717. http://dx.doi.org/10.3390/ polym12030704. PMid:32235772.

Received: May 04, 2020

Revised: June 22, 2020

Accepted: June 26, 2020 